\title{
Identification key for fishes from coastal streams of the Atlantic forest of southeastern Brazil
}

\author{
Cristina da Silva Gonçalves ${ }^{1}$, Fernando Rogério Carvalho², María Angélica Pérez-Mayorga ${ }^{3}$ \& \\ Isadora Francesconi de Oliveira ${ }^{I}$ \\ ${ }^{1}$ Universidade Estadual Paulista “Júlio de Mesquita Filho”, Departamento de Zoologia, Rio Claro, SP, Brazil \\ ${ }^{2}$ Universidade Federal de Mato Grosso do Sul, Instituto de Biociências, Laboratório de Ictiologia, Avenida Costa e \\ Silva, s/n, Cidade Universitária, Campo Grande, MS, Brazil \\ ${ }^{3}$ Universidade Estadual Paulista "Júlio de Mesquita Filho”, Departamento de Zoologia e Botânica, \\ São José do Rio Preto, SP, Brazil \\ *Corresponding author: Cristina S. Gonçalves, e-mail: cristina.silva.goncalves@gmail.com
}

GONÇALVES, C. S., CARVALHO, F. R., PÉREZ-MAYORGA, M. A., OLIVEIRA, I. F. Identification key for fishes from coastal streams of the Atlantic forest of southeastern Brazil. Biota Neotropica. 17(4): e20170377. http://dx.doi. org/10.1590/1676-0611-BN-2017-0377

\begin{abstract}
In recent decades, current knowledge about fish from Neotropical streams has greatly increased, but is still deficient. Here we present an identification key for fishes from coastal freshwater streams from a large conservation area of Atlantic rainforest of southeastern Brazil, including 39 species. Considering that most of these species (61.2\%) are endemic to the coastal streams, this identification key will be useful not only for the species recognition of the sampled area, but also for the surrounding coastal region.
\end{abstract}

Keywords: taxonomy, endemic and endangered fishes, Neotropical streams, Juréia-Itatins Ecological Station.

\section{Chave de identificação para os peixes de riachos costeiros da Mata Atlântica, sudeste do Brasil}

\begin{abstract}
Resumo: Nas últimas décadas, o conhecimento acerca dos peixes de riachos neotropicais aumentou consideravelmente, mas apesar disso ainda é deficiente. Apresentamos aqui uma chave de identificação para as 39 espécies de peixes de uma grande unidade de conservação da Mata Atlântica do sudeste do Brasil. Considerando que a maioria destas espécies $(61,2 \%)$ são endêmicas dos riachos costeiros, esta chave de identificação será útil não só para o reconhecimento de espécies da área amostrada, mas também da região costeira do entorno.
\end{abstract}

Palavras-chave: taxonomia, peixes endêmicos e ameaçados, riachos neotropicais, Estação Ecológica Juréia-Itatins.

\section{Introduction}

The Serra do Mar was formed from an uplift process during the Cretaceous, which originated a sequence of $1,000 \mathrm{~km}$ of mountains near the newly formed coast. Its current relief was shaped over millions of years by erosion and tectonic activities and currently covers the states of Rio de Janeiro to Santa Catarina (Oyakawa et al. 2006). The Atlantic forest is a complex biome that covers practically the entire Serra do Mar, and although human occupation has degraded $90 \%$ of its area, this biome harbors a significant part of the Brazilian biodiversity (Joly et al. 1999); 40\% of the 2,000 vertebrate species are endemic (Oyakawa et al. 2006).

In this region, there are mountain streams with clear and fast waters due to the high slope of the relief, low temperatures and high concentration of dissolved oxygen, and the lowland streams that drains the less steep coastal plain forming meanders with black, slower, turbid and acidic waters with higher temperatures, lower dissolved oxygen concentration and sandy bottom (Por 2004). Due to the altitudinal gradient, coastal streams rise with waters typical of mountain streams that change when they reach the plains and with the proximity of the mouth in the sea (Gonçalves \& Braga 2012).

These and other habitat characteristics influence the ichthyofauna of coastal streams (Abilhoa et al. 2011, Barrella et al. 2014, Gonçalves et al. 2015). The conservation of riparian forest is important since deforestation negatively impacts the survival of fish due to silting, increased sunlight incidence and decreased invertebrate fauna, among other impacts (Lorion \& Kennedy 2009, Leite et al. 2015). This can lead to drastic consequences such as changes in reproductive and feeding behaviors of many species (Menezes et al. 2007, Ferreira et al. 2012, Lobón-Cerviá et al. 2016).

The Juréia-Itatins Ecological Station is a conservation unit on the south coast of the state of São Paulo with streams that protects several endemic species (and some endangered) of the Atlantic forest (Gonçalves \& Braga 2013, Gonçalves et al. 2016, Gonçalves \& Pérez-Mayorga 2016). Characiformes and Siluriformes are predominant, but other orders such as Cichliformes 
and Gobiiformes (sensu Betancur-R et al. 2017), Synbranchiformes, Cyprinodontiformes, and Gymnotiformes are also present (Gonçalves \& Pérez-Mayorga 2016), as well as primarily marine families (Sabino \& Silva 2004). Fish occupy different stream reaches according to their feeding habits and swimming capacity, varying between rapids, marginal backwaters or position in the water column (Sabino \& Silva 2004). In the freshwater streams of of Juréia-Itatins Ecological Station, fish feed primarily on resources provided by riparian forest, such as terrestrial insects and vegetable debris (also consumed by immature forms of aquatic insects that will feed aquatic insectivorous fish), stressing the importance of legally protected areas in Atlantic forest (Gonçalves et al. 2013). The small size of most species of these coastal streams and the scarcity of keys can make it difficult to identify the fish of this region. The objective of this paper is to provide an identification key for fishes from coastal streams of JuréiaItatins Ecological Station.

\section{Material and Methods}

The material used in this study was collected every three months between April 2009 and February 2010, and once in June 2013 (cf. Gonçalves \& Braga 2012, 2013, Gonçalves \& Pérez-Mayorga 2016) at the Juréia-Itatins reserve, an Atlantic rainforest pristine area with 79.240 ha on the south coast in the State of São Paulo, Brazil (2418', 24³2' S and $\left.47^{\circ} 00^{\prime}, 47^{\circ} 30^{\prime} \mathrm{W}\right)$. Average annual rainfall and temperature are $2,277 \mathrm{~mm}$ and $21.4^{\circ} \mathrm{C}$, respectively. A hot and rainy season occurs from October to April, and the less rainy season from May to September (Marques \& Duleba 2004). Altitudes vary from sea level at alluvial plains to $1,240 \mathrm{~m}$ a.s.l. at steep mountains (Por 1986, Souza \& Souza 2004). Due to this, local hydrography is influenced by the different vegetation types of dense ombrophilous forest found at different elevation: black waters (rich in humic substances with $\mathrm{pH}$ ca. 4) drains the alluvial dense ombrophilous forest and the lowland dense ombrophilous forest (also known as restinga forest), and clear waters (nutrient poor with $\mathrm{pH}$ ca. 6) drains the submontane dense ombrophilous forest and the montane dense ombrophilous forest (Por 1986, Por \& Lopes 1994, Por 2004). Fish were sampled at 73 locations, using electrofishing, fishing nets, traps, and sieve (Gonçalves \& Pérez-Mayorga 2016). Specimens were anesthetized with benzocaine, fixed in $10 \%$ formalin, and then kept in $70 \%$ ethanol until the analysis. Counts were taken on the left side of specimens as proposed by Fink \& Weitzman (1974). The identification key provided was based on easily recognizable external morphological characters in most cases. The fishes classification followed Betancur-R et al. (2017). Voucher specimens (Table 1) are deposited in the fish collections of Universidade Estadual Paulista "Júlio de Mesquita Filho" (UNESP/DZSJRP), Câmpus São José do Rio Preto, and Museu de Zoologia of Universidade de São Paulo (MZUSP), São Paulo, Brazil.

Table 1. The thirty-nine fish species registered in the coastal freshwater streams from Juréia-Itatins Ecological Station, a large conservation area of Atlantic rainfores of southeastern Brazil. (1) endemic to the Atlantic forest (Menezes et al. 2007), (2) endangered fish (State Decree $\mathrm{N}^{\circ}$ 60.133 07/02/2014), (-) voucher not available.

\begin{tabular}{|c|c|c|}
\hline Order/Family & Species & Voucher \\
\hline \multicolumn{3}{|l|}{ CHARACIFORMES } \\
\hline Curimatidae & ${ }^{1}$ Cyphocharax santacatarinae (Fernández-Yépez, 1948) & DZSJRP 20732 \\
\hline \multirow[t]{3}{*}{ Crenuchidae } & ${ }^{I}$ Characidium lanei Travassos, 1967 & DZSJRP 20733 \\
\hline & ${ }^{1}$ Characidium pterostictum Gomes, 1947 & DZSJRP 20738 \\
\hline & ${ }^{1,2}$ Characidium schubarti Travassos, 1955 & DZSJRP 13252 \\
\hline \multirow[t]{7}{*}{ Characidae } & ${ }^{1}$ Astyanax ribeirae Eigenmann, 1911 & DZSJRP 13256 \\
\hline & ${ }^{1}$ Deuterodon iguape Eigenmann, 1907 & DZSJRP 13240 \\
\hline & ${ }^{1}$ Hollandichthys multifasciatus (Eigenmann \& Norris, 1900) & DZSJRP 13253 \\
\hline & ${ }^{1}$ Hyphessobrycon griemi Hoedeman, 1957 & DZSJRP 13247 \\
\hline & ${ }^{1}$ Hyphessobrycon boulengeri (Eigenmann, 1907) & DZSJRP 13248 \\
\hline & ${ }^{I}$ Mimagoniates microlepis (Steindachner, 1877) & DZSJRP 13250 \\
\hline & ${ }^{1}$ Oligosarcus hepsetus (Cuvier, 1829) & DZSJRP 13251 \\
\hline Erythrinidae & Hoplias cf. malabaricus (Bloch, 1794) & DZSJRP 13238 \\
\hline \multicolumn{3}{|l|}{ SILURIFORMES } \\
\hline Ariidae & Genidens genidens (Lacepède, 1803) & - \\
\hline \multirow[t]{3}{*}{ Callichthyidae } & ${ }^{1}$ Scleromystax barbatus (Quoy \& Gaimard, 1824) & DZSJRP 13242 \\
\hline & ${ }^{1,2}$ Scleromystax macropterus (Regan, 1913) & DZSJRP 13246 \\
\hline & ${ }^{1,2}$ Scleromystax prionotos (Nijssen \& Isbrücker, 1980) & DZSJRP 20740 \\
\hline \multirow[t]{4}{*}{ Loricariidae } & ${ }^{1}$ Kronichthys heylandi (Boulenger, 1900) & DZSJRP 13262 \\
\hline & ${ }^{1}$ Pseudotothyris obtusa (Miranda Ribeiro, 1911) & DZSJRP 13245 \\
\hline & Rineloricaria sp. & DZSJRP 20729 \\
\hline & ${ }^{1}$ Schizolecis guntheri (Miranda Ribeiro, 1918) & DZSJRP 13239 \\
\hline Pseudopimelodidae & ${ }^{1}$ Microglanis cf. parahybae (Steindachner, 1880) & DZSJRP 20737 \\
\hline \multirow[t]{4}{*}{ Heptapteridae } & ${ }^{1}$ Acentronichthys leptos Eigenmann \& Eigenmann, 1889 & DZSJRP 13254 \\
\hline & ${ }^{1}$ Pimelodella transitoria Miranda Ribeiro, 1907 & DZSJRP 13244 \\
\hline & Rhamdia aff. quelen (Quoy \& Gaimard, 1824) & DZSJRP 20735 \\
\hline & ${ }^{I}$ Rhamdioglanis transfasciatus Miranda Ribeiro, 1908 & DZSJRP 20728 \\
\hline \multicolumn{3}{|l|}{ GYMNOTIFORMES } \\
\hline Gymnotidae & ${ }^{I}$ Gymnotus pantherinus (Steindachner, 1908) & DZSJRP 13255 \\
\hline \multicolumn{3}{|l|}{ CYPRINODONTIFORMES } \\
\hline Aplocheilidae & ${ }^{1}$ Atlantirivulus santensis (Köhler, 1906) & DZSJRP 13257 \\
\hline \multirow[t]{3}{*}{ Poeciliidae } & Phalloceros harpagos Lucinda, 2008 & DZSJRP 20739 \\
\hline & ${ }^{I}$ Phalloceros reisi Lucinda, 2008 & DZSJRP 13236 \\
\hline & Poecilia vivipara Bloch \& Schneider, 1801 & DZSJRP 13237 \\
\hline
\end{tabular}


Table 1. Continued...

\begin{tabular}{|c|c|c|}
\hline Order/Family & Species & Voucher \\
\hline \multicolumn{3}{|l|}{ SYNBRANCHIFORMES } \\
\hline Synbranchidae & Synbranchus aff. marmoratus Bloch, 1795 & DZSJRP 13241 \\
\hline \multicolumn{3}{|c|}{ INCERTAE SEDIS in CARANGARIA } \\
\hline Centropomidae & Centropomus parallelus Poey, 1860 & - \\
\hline \multicolumn{3}{|l|}{ CICHLIFORMES } \\
\hline \multirow[t]{2}{*}{ Cichlidae } & Crenicichla cf. tingui Kullander \& Lucena, 2006 & DZSJRP 20736 \\
\hline & Geophagus brasiliensis (Quoy \& Gaimard, 1824) & DZSJRP 13234 \\
\hline \multicolumn{3}{|l|}{ GOBIIFORMES } \\
\hline \multirow[t]{2}{*}{ Eleotridae } & Dormitator maculatus (Bloch, 1792) & DZSJRP 20731 \\
\hline & Eleotris pisonis (Gmelin, 1789) & MZUSP 110173 \\
\hline \multirow[t]{3}{*}{ Gobiidae } & Awaous tajasica (Lichtenstein, 1822) & DZSJRP 20734 \\
\hline & Bathygobius soporator (Valenciennes, 1837) & DZSJRP 20730 \\
\hline & Ctenogobius shufeldti (Jordan \& Eigenmann, 1887) & MZUSP 110175 \\
\hline
\end{tabular}

\section{Identification key for fishes from coastal streams of the Atlantic forest of southeastern Brazil.}

1. Fins present, at least pectorals and anal; two opercular openings ......... 2

1 '. Fins absent (or vestigial); a single opercular opening, ventral Synbranchus aff. marmoratus (Synbranchiformes)

2. Dorsal and caudal fins present; less than 100 branched anal fin rays ........... 3

2'. Dorsal and caudal fins absent; more than 200 branched anal fin rays. Gymnotus pantherinus (Gymnotiformes)

3. Body naked or covered with bony plates; barbels present (sometimes small) 20 (Siluriformes)

3'. Body covered with scales; barbels absent .. 4

4. Dorsal fin with 11 or less soft rays, i.e., not transformed into spines 5

4'. Dorsal fin with more than 12 rays, the first normally rigid, transformed into spines

5. Scales covering the head, dorsally; premaxilla protractile, i.e., moving in front of the skull; small body size, maximum standard length less than $60 \mathrm{~mm}$ 6 (Cyprinodontiformes)

5'. Scales absent in the dorsal portion of the head; premaxilla non-protractile, i.e., does not move in front of the skull; maximum standard length normally more than $70 \mathrm{~mm}$ 9 (Characiformes)

6. Anal fin of mature males with modified rays, i.e., transformed into a gonopodium; dorsal fin at vertical through the mid-posterior portion in flank, its longer rays never extending to the beginning of caudal fin; flank scales with chromatophores at its edges, forming a reticulated pattern

7

6'. Anal fin of mature males with normal rays, not transformed into a gonopodium; dorsal fin posterior to the middle in flank, its larger rays extending to the beginning of caudal fin; flank scales with chromatophores uniformly distributed in their area Atlantirivulus santensis (Aplocheilidae)

7. No sexual color dimorphism, males showing the same color as females; pelvic fin of mature males anteriorly displaced, its origin located at vertical through pectoral fin origin; females with developed urogenital papilla, displaced after anal fin origin, and with spots vertically elongated in flank ... 8 (Phalloceros)
7'. Conspicuous sexual color dimorphism, males more colorful than females; pelvic fin of the mature males posteriorly displaced, its origin near the anal fin origin; females without developed urogenital papilla, and normally without spot in flank Poecilia vivipara

8. Female urogenital papilla approximately rectilinear along the mid-ventral line, between the anus and the base of first anal fin ray; border of the anal aperture separated from the first anal fin ray by the urogenital papilla ...... Phalloceros harpagos

8'. Female urogenital papilla curved to the right, laterally; border of the anal aperture in contact with the first anal fin ray or close to it

Phalloceros reisi

9. Jaw teeth present, even if small; humeral spot present or absent and/or spot in the caudal peduncle normally absent; when present restricted to the medial portion of the caudal peduncle. 10

9'. Jaw teeth absent; humeral spot absent, but with large spot in the caudal peduncle, relatively rounded ....... Cyphocharax santacatarinae (Curimatidae)

10. Adipose fin present; forked caudal fin 11

10'. Adipose fin absent; rounded caudal fin Hoplias cf. malabaricus (Erythrinidae)

11. Jaw teeth with three or more cusps; lateral line with less than 40 perforated scales; small mouth, its opening does not extend until the vertical that passes through the origin of the orbit .. 12

11'. Canine and conical jaw teeth; lateral line with more than 45 perforated scales; wide mouth opening, extending to the vertical through the origin of the orbit Oligosarcus hepsetus (Characidae)

12. Anal fin with less than 10 branched rays; dark band between snout and the orbit present; premaxilla with conical or tricuspid teeth

13 (Characidium)

12'. Anal fin with more than 10 rays; dark band between snout and the orbit absent; premaxillary teeth with four or more cusps .. 15

13. Dark longitudinal stripe on flank with relatively irregular borders, with spots projecting dorsally and/or ventrally 14

13'. Dark longitudinal stripe on flank with approximately straight edge, with small spots (not covering one scale size) below the dark longitudinal stripe . Characidium schubarti 
14. Caudal and adipose fins hyaline; dark spots below the dark longitudinal stripe not extending to pelvic fin origin Characidium lanei

14'. Caudal fin with dark spots; blackened adipose fin; dark spots below the dark longitudinal stripe extending to pelvic fin origin

Characidium pterostictum

15. Lateral line complete 16

15'. Lateral line incomplete 17

16. Large mouth opening, extending to the vertical that passes through the nostrils origin, teeth of the inner row of the premaxillary with up to nine cusps; mature males without bony hooks in anal fin; 3-4 (mode 3) maxillary teeth.

Deuterodon iguape

16'. Small mouth opening, distinctly anterior to the vertical that passes through the nostrils origin, teeth of the inner row of the premaxillary with up to seven cusps; mature males with bony hooks in anal fin; 1-3 (mode 2) maxillary teeth. Astyanax ribeirae

17. Flank with a dark stripe or absent stripes; humeral blotch present ..... 18

17'. Flank with several black stripes, usually forming a zigzag pattern; humeral blotch absent. Hollandichthys multifasciatus

18. One humeral spot; spot in caudal peduncle present 19

18'. Two humeral spots; spot in caudal peduncle absent

Hyphessobrycon griemi

19. Narrow longitudinal stripe on flank, covering less than one scale in longitudinal series; origin of the dorsal fin vertically passing before the origin of the anal fin; flank scales with reticulated pattern; anal fin with $15-22$ branched rays Hyphessobrycon boulengeri

19'. Relatively wide longitudinal stripe on flank, covering two or more longitudinal series of scales; origin of the dorsal fin distinctly posterior to the vertical that passes before the origin of the anal fin; flank scales hyaline or with sparse chromatophores; anal fin with 26-31 branched rays

Mimagoniates microlepis

20. Body covered with bony plates ... 21

20'. Body naked, i.e., covered by thick skin 27

21. Body covered with two longitudinal rows of bone plates, plain (without lateral keels), subterminal mouth (not modified into a sucking disk)

22 (Callichthyidae)

21'. Body covered with four or more longitudinal rows of bone plates, normally with small lateral keels; inferior mouth, modified into a sucking disk . 24 (Loricariidae)

22. Longitudinal stripe faded or absent on flank; blotches projecting dorsally and/or ventrally on flank; dark stripe below longitudinal stripe extending from the pelvic fin to the anal fin absent; uniformly colored head, with chromatophores uniformly scattered .

.. 23

22'. Median dark longitudinal stripe conspicuous on flank, followed below by a narrow dark stripe extending from the pelvic fin to the anal fin; blotches projecting ventrally on flank absent; head with dark coloration, and small golden spots

Scleromystax barbatus

23. Three or four vertical dark blotches on the flank, caudal fin with dark narrow stripes Scleromystax macropterus

23'. Blotches on flank absent, with chromatophores uniformly scattered in the caudal fin Scleromystax prionotos

24. Adipose fin absent .25

24'. Adipose fin present.. Kronichthys heylandi
25. Caudal peduncle rounded, without conspicuous lateral keels ........ 26

25'. Caudal peduncle depressed, with two conspicuous lateral keels ........ Rineloricaria sp.

26. Pectoral girdle totally exposed, posterior portion of the supraoccipital with well-developed odontodes in adults Pseudotothyris obtusa

26'. Pectoral girdle covered by skin, exposed only laterally, posterior portion of the supraoccipital without odontodes in adults

Schizolecis guntheri

27. Gill membranes are free to each other and to the isthmus; adipose fin origin anterior to anal fin origin 28

27'. Gill membranes joined to each other and to the isthmus; adipose fin origin at vertical or posterior to anal fin origin

Genidens genidens (Ariidae)

28. Free orbital margin, i.e., eyes not covered by skin; hyaline dorsal fin or with sparse chromatophores, evenly distributed; flank with longitudinal dark stripes . 29 (Heptapteridae)

28'. Orbital margin not free, i.e., orbital margin covered by skin; dorsal fin with conspicuous dark blotches; flank with vertical dark stripes Microglanis cf. parahybae

29. Dorsal fin origin distinctly ahead at vertical through pelvic fin origin; adipose fin not extending to caudal fin origin (free caudal peduncle dorsally) .. 30

29'. Dorsal fin origin proximately at vertical through pelvic fin origin; adipose fin elongate, extending to caudal fin origin (covering the caudal peduncle area) Acentronichthys leptos

30. Maxillary barbell short, not extending to anal fin origin; flank with longitudinally conspicuous dark stripe or dorsally dark stripes; adipose fin origin at vertical through posterior base of pelvic fin 31

30'. Maxillary barbell long, extending to anal fin origin; flank uniformly colored; adipose fin origin at vertical through middle base of pelvic fin.... Rhamdia aff. quelen

31. Long supraoccipital process, reaching the dorsal fin origin; longitudinal dark stripe extending at vertical through dorsal fin origin to caudal peduncle end; maxillary barbell long, surpassing the pelvic fin origin

Pimelodella transitoria

31'. Short supraoccipital process, not reaching the dorsal fin origin; longitudinal dark stripe absent; albeit with dorsal dark stripes; maxillary barbell short, not reaching the pelvic fin origin

Rhamdioglanis transfasciatus

32. Single dorsal fin, i.e., undivided; lateral line divided into two portions: upper dorsal and inferior ventral 33 (Cichliformes)

32'. Dorsal fin divided into two parts; single lateral line, undivided ....... 34

33. Dark longitudinal stripe extending from eye to caudal peduncle; preopercular posterior margin serrated; rounded spot in the upper portion of caudal fin beginning; first gill arch without lobe in its upper portion .....

Crenicichla tingui

33'. Humeral spot rounded in the medial portion in flank; preopercular posterior margin smooth; dark spot in caudal fin absent; first gill arch with developed lobe

Geophagus brasiliensis 
34. Caudal fin not bifurcated, i.e. emarginated, truncated, tapered or rounded; yellowish brownish flank, with dark blotches or concentrated chromatophores; small sized body, less than $60 \mathrm{~cm}$ in total length

35 (Gobiiformes)

34'. Caudal fin bifurcated; silver flank, without dark blotches, and blackened lateral line; mid-sized body - ca. $70 \mathrm{~cm}$ in total length

... Centropomus parallelus (Centropomidae - Incertae Sedis in Carangaria)

35. Terminal or slightly superior mouth; free pelvic fins or with attached bases, but not forming an adhesive disk 36 (Eleotridae)

35'. Slightly inferior mouth; pelvic fins attached by a membrane, forming an adhesive disk 37 (Gobiidae)

36. Dark stripe below the eye extending to the dentary; 25-35 scales along longitudinal series; preopercular spine absent

Dormitator maculatus

36'. Dark stripe below the eye absent; more than 40 scales in a longitudinal series; preopercular spine present Eleotris pisonis

37. Scales on flank beginning at the vertical through the end of the opercular bone; a pair of anterior interorbital pores present; two or three dark stripes on the nostril ... 38

37'. Scales in the superior portion of the head extending until at vertical through preopercule; normally a single anterorbital pore; dark stripes on the nostril absent Bathygobius soporator

38. Caudal fin truncated or slightly rounded; two dark stripes between the orbit and the nostril; gill rakers present in the upper portion of the first branchial arch

Awaous tajasica

38'. Posteriorly tapered caudal fin; three dark stripes between the orbit and the nostril; gill rakers in the upper portion of the first branchial arch absent Ctenogobius shufeldti

\section{Results}

Seven orders, 17 families, and 39 fish species were identified (Table 1). Siluriformes were the most representative order (five families and 13 species), followed by Characiformes (four families and 12 species), Gobiiformes (two families and five species), and Cyprinodontiformes (two families and four species). Gymnotiformes and Synbranchiformes were represented by one species, each one. Twenty-four species (61.5\%) are endemic to the Atlantic forest, and three are endangered (Table 1). An identification key for fishes from coastal streams of Juréia-Itatins Ecological Station is provided.

\section{Discussion}

In recent decades, current knowledge about fish from Neotropical streams has increased but is still deficient, even in better-exploited regions as southeastern Brazil. Juréia-Itatins Ecological Station represents an important refuge for the conservation of stream fishes, especially Characidium schubarti, Scleromystax macropterus, and S. prionotos that are threatened with extinction in the state of São Paulo since 2014 (State Decree 60.133), as well as Pseudocorynopoma heterandria, Hoplias lacerdae, and Brachyhypopomus jureiae, sampled during other studies (Sabino \& Silva 2004, Oyakawa et al. 2006). The main threat to species found in lowland streams such as $S$. macropterus is the deforestation of restinga (Gonçalves et al. 2016). Furthermore, the studied area has a great regional diversity of fishes, since the high diversity of aquatic environments (e.g. mountain streams with clear waters, lowland streams with black waters, and estuarine rivers with brackish waters), allows a greater diversity of species (Gonçalves \& Braga 2012, Ferreira et al. 2014).

An identification key for Atlantic forest fish was published by Oyakawa et al. (2006), but only mentioned 16 of the 39 species reported by us in Juréia-Itatins Ecological Station streams. The present identification key will be useful for the recognition of species in the studied area, especially if used jointly with the color guide available online for free (Gonçalves 2014), which contains 38 photos of the Juréia-Itatins Ecological Station fish. Considering that most of these species are endemic to the coastal streams, this identification key will be useful not only for the species recognition of the sampled area, but also for the surrounding coastal region.

\section{Acknowledgments}

We appreciate the support from César Cestari, Ílson Prado, and Juréia-Itatins Ecological Station' staff for facilities during the fieldwork. We thank IBAMA/ICMBio (37489-1/2; 15744) and COTEC (260108-015.708/2012; 260108-000.197/2008) for licenses. CSG received grants from FAPESP (2008/55029-5, 2012/19723-0), and CAPES. MAPM is supported by the Post-Doctoral Program of IBILCE, UNESP.

\section{Author Contributions}

Cristina da Silva Gonçalves: substantial contribution in the concept and design of the study; contribution to data collection; contribution to data analysis and interpretation; contribution to manuscript preparation and critical revision.

Fernando Rogério Carvalho: substantial contribution in the concept and design of the study; contribution to data analysis and interpretation; contribution to manuscript preparation and critical revision.

María Angélica Pérez Mayorga: contribution in the concept and design of the study; contribution to data analysis and interpretation; contribution to manuscript preparation and revision.

Isadora Francesconi de Oliveira: contribution to data analysis and interpretation; contribution to manuscript preparation and revision.

\section{Conflicts of interest}

The authors declare that they have no conflict of interest related to the publication of this manuscript.

\section{References}

ABILHOA, V., BRAGA, R.R., BORNATOWSKI, H. \& VITULE, J.R.S. 2011. Fishes of the Atlantic rain forest streams: ecological patterns and conservation. In Changing diversity in changing environment. (O. Grillo, ed.). Rijeka: InTech, p. 259-282.

BARRELLA, W., MARTINS, A.G., PETRERE Jr. M. \& RAMIRES M. 2014. Fishes of the southeastern Brazil Atlantic Forest. Environ. Biol. Fish. 97(12):1367-1376.

BETANCUR-R, R., WILEY, E.O., ARRATIA, G., ACERO, A., BAILLY, N., MIYA, M., LECOINTRE, G. \& ORTÍ, G. 2017.Phylogenetic classification of bony fishes. BMC Evol. Biol. 17:162.

FERREIRA, A., PAULA, F.R., FERRAZ, S.F.B., GERHARD, P., KASHIWAQUI, E.A.L., CYRINO, J.E.P. \& MARTINELLI, L.A. 2012. Riparian coverage affects diets of characids in neotropical streams. Ecol. Freshw. Fish. 21(1):12-22.

FERREIRA, F.C., SILVA, A.T., GONÇALVES, C.S. \& PETRERE, Jr. M. 2014. Disentangling the influences of habitat structure and limnological predictors on stream fish communities of a coastal basin, southeastern Brazil. Neotrop. Ichthyol. 12(1):177-186.

FINK, W.L. \& WEITZMAN, S.H. 1974. The so-called Cheirodontin fishes of Central America with descriptions of two new species (Pisces: Characidae). Smithsonian Contributions to Zoology. 172:1-46.

GONÇALVES, C.S. \& BRAGA, F.M.S. 2012. Changes in ichthyofauna composition along a gradient from clearwaters to blackwaters in coastal streams of Atlantic forest (southeastern Brazil) in relation to environmental variables. Neotrop. Ichthyol. 10:675-684.

GONÇALVES, C.S. \& BRAGA, F.M.S. 2013. Checklist of freshwater ichthyofauna from coastal streams of Juréia-Itatins reserve, southeastern Brazil. Check List 9:175-185. 
GONÇALVES, C.S. \& PÉREZ-MAYORGA, M.A. 2016. Peixes de riachos da Estação Ecológica Juréia-Itatins: estrutura e conservação. UNISANTA Bioscience Volume Especial "Juréia-Itatins" 5(1): 42-55.

GONÇALVES, C.S. 2014. Rapid color guide to stream fish from Atlantic rainforest. The Field Museum: Chicago, IL. Available at: http://fm2.fieldmuseum.org/ plantguides/guideimages.asp?ID=662. Accessed 5 April 2017.

GONÇALVES, C.S., BRAGA, F.M.S. \& CASATTI, L. 2013. Characterization of trophic structure and determination of riparian vegetation importance for fish's diet from coastal streams of Atlantic forest. In 50th Anniversary Meeting of the Association of Tropical Biology and Conservation: San Jose, Costa Rica Available at: https://atbc.confex.com/atbc/2013/webprogram/Paper2553.html. Accessed 8 May 2017.

GONÇALVES, C.S., FERREIRA, F.C. \& SILVA, A.T. 2016. Scleromystax macropterus e Mimagoniates lateralis: dois peixes de riachos de restinga ameaçados de extinção devido a perda de hábitat. Boletim SBI 16:12-15.

GONÇALVES, C.S., HOLT, R., CHRISTMAN, M. \& CASATTI, L. 2015. Environmental and spatial influences on stream fish metacommunities in the Atlantic rainforest, southeast Brazil. In XXI Encontro Brasileiro de Ictiologia: Recife, Pernambuco. p.526-526.

JOLY, C.A., AIDAR, M.P.M., KLINK, C.A., MCGRATH, D.G., MOREIRA, A.G., MOUTINHO, P., NEPSTAD, D.C., OLIVEIRA, A.A., POTT, A., RODAL, M.J.N. \& SAMPAIO, E.V.S.B. 1999. Evolution of the Brazilian phytogeography classification systems: implications for biodiversity conservation. Ciência e Cultura 51(5-6):331-348

LEITE, G.F.M., SILVA, F.T.C., GONÇALVES, J.F. Jr \& SALLES, P. 2015. Effects of conservation status of the riparian vegetation on fish assemblage structure in neotropical headwater streams. Hydrobiologia 762(1):223-238.

LOBÓN-CERVIÁ, J., MAZZONI, R. \& REZENDE, C.F. 2016. Effects of riparian forest removal on the trophic dynamics of a Neotropical stream fish assemblage. J. Fish Biol. 89(1):50-64.
LORION, C.M. \& KENNEDY, B.P. 2009. Relationships between deforestation, riparian forest buffers, and benthic macroinvertebrates in neotropical headwater streams. Freshwater Biol. 54(1):165-180.

MARQUES, O.A.V. \& DULEBA, W. 2004. Estação Ecológica Juréia-Itatins: ambiente físico, flora e fauna. Holos, Ribeirão Preto.

MENEZES, N.A., WEITZMAN, S.H., OYAKAWA, O.T., LIMA, F.C.T., CASTRO, R.M.C. \& WEITZMAN, M.J. 2007. Peixes de água doce da Mata Atlântica: lista preliminar das espécies e comentários sobre conservação de peixes de água doce neotropicais. São Paulo: MZUSP.

OYAKAWA, O.T., AKAMA, A., MAUTARI, K.C. \& NOLASCO, J.C. 2006. Peixes de riachos de Mata Atlântica nas Unidades de Conservação do Vale do rio Ribeira de Iguape no Estado de São Paulo. Neotrópica, São Paulo.

POR, F.D. \& LOPES, R.M. 1994. The streams of the Atlantic rainforest of Brazil. Verh. int. Verein. Limnol. 25:1871-1875.

POR, F.D. 1986. Stream type diversity in the Atlantic lowland of the Juréia area (Subtropical Brazil). Hydrobiologia 131:39-45.

POR, F.D. 2004. Hidrobiologia da Juréia e da baixada do Ribeira - rios e manguezais In Estação Ecológica Juréia-Itatins: ambiente físico, flora e fauna. Holos, Ribeirão Preto (O.A.V. Marques \& W. Duleba, eds.). Holos, Ribeirão Preto, p.51-57.

SABINO, J. \& SILVA, C.P.D. 2004. História natural de peixes da Estação Ecológica Juréia-Itatins. In Estação Ecológica Juréia-Itatins: ambiente físico, flora e fauna. (O.A.V. Marques \& W. Duleba, eds.). Holos, Ribeirão Preto, p.230-242.

SOUZA, C.R. de G. \& SOUZA, A.P. 2004. Geologia e geomorfologia da área da Estação Ecológica Juréia-Itatins. In Estação Ecológica Juréia-Itatins: ambiente físico, flora e fauna (O.A.V Marques \& W. Duleba, eds.). Holos, Ribeirão Preto, p.16-33.

Received: 10/05/2017

Revised: 07/11/2017

Accepted: 22/11/2017

Published online: 11/12/2017 